\title{
Versifying Unease in Postcolonial Nigerian Society: Politics of Corruption and Oppression in Akan Essien's Stabbed Alive. Rage Alive and Halima Amali's I Want to Join Them
}

\author{
Raphael Chukwuemeka Onyejizu \\ http://dx.doi./org/10.4314/ujah.v22i1.8
}

\section{Abstract}

Postcolonial Nigerian society is confronted by corruption and oppression that emerged in the wake of independence. In recent times, these challenges have evolved in the creative consciousness of writers in their versified writings. Poetry, which serves as a veritable medium for the projection of philosophical thought, reflects these vagaries as the unique genre employed by poets for humanity that is dismayed by the irony of hope and survival. This paper examines corruption in politics and oppression of the masses. It showed that the drawbacks witnessed in the country attribute to the aforementioned variables. The choice of Essien's Rage Alive. Stabbed Alive (2010) and Amali's I Want to Join Them (2016) is informed by the fact that there is a lack of scholarly research on these collections. The paper adopts spivak's postcolonial framework in the context of the Nigerian society, while the descriptive method of textual analysis aimed to show how political leaders in their deployment of corrupt and oppressive schemes, advance their kleptomaniac agenda. Thus, the study submits that for a functional and progressive society to exist, fundamental changes in its socio-political affairs must be undertaken.

\section{Keywords: Poetry, politics, corruption, oppression, commitment}




\section{Introduction}

Poetry has become a weapon for cross-examining the socio-political problems of immediate and distant societies of the world. It serves as an instrument for galvanising societies where we live, co-exist and share distinct value systems, experiences, fears, hope, fortunes, anxieties, and identities. Through the illustrious and visionary efforts of poets and versifiers whose role align with the moral crusaders, watchdogs, visionaries, prophets and seers, the challenges bisecting societies have successfully come to limelight. Thus, this success is not farfetched from the humanist ideal for transformation against those quandaries bedevilling societies from the viewpoints of politics, economy, religion, security and education.

Postcolonial poetry in Nigeria, as with other African enclaves, often updates us with the persistent outcomes of leadership misrule peculiar with African states, its byproducts of political corruption in the public sphere and the oppression of the masses. These challenges have found critical and theoretical basis in the formative ideologies and thematic trajectory of poetry in the period leading up to its production in contemporary times. The significance of this development in current discourse by scholars is immense, given the degree of salvific cum humanist quest for socio-political change in their various domains. In recent times, this remediating endeavor by the Nigerian poet has continued to stimulate major concerns of poetry in African literature. Within Nigeria's landscape, the major topical issues addressed in their polemics have resulted in the formation of the literature of disillusionment as evidenced in public outcries and consistent lacrymocities, witnessed throughout post-independence. However, the current trend in postcolonial Nigerian poetry shows that leadership, whose historical antecedents from independence, has culminated in the erosion of transparency 
in the public sphere, and this has regrettably, birthed the continuous oppression of the masses or electorates.

\section{Corruption}

Scholars in the fields of politics, literature and sociology view corruption as the major bane to a nation's development and as a source of conflicts in modern societies. The creative burden of Nigerian poets in their meditative, socio-political and revolutionary aspirations towards salvaging the society from plunder and ruin, reflects these quandaries. Moreover, the complexity in defining corruption lies in the various attempts at rationalizing its multidimensional perspectives by writers and scholars. Thus, Agbese (1992) agrees that it as a complex trend, which "percolates every structure of the society." He captures its manifestations through individual conscious or unconscious practice that:

When we use our position in society to secure certain advantages jumping a queue, being waved off at checkpoint or making others bend the rules to accommodate our demands ... by whatever means if is just 'thank you' our action however innocent, however well-intentional, however unthreatening to others, has corrupted a system or convention or some rules and regulations in application (9).

In the same vein, Turner, Singleton \& Musick in K.E. Davis (1984) (ed) view corruption as a kind of denial of rare resources by a particular people towards another group as constituents of the society. He notes that it is:

...a situation in which one or more identifiable segments of the population in a social system systematically and successfully acts over a 
prolonged period of time to prevent another identifiable segment or segments of the population from attaining access to the scares and valued resources of that system (520).

However, Khan (1996), sees corruption specifically as a human tendency in a privileged position; a "behaviour which deviates from the formal rules of conduct governing the actions of someone in a position of public authority because of privateregarding motives such as wealth, power, or status"(12). Besides, Okolo \& Akpokighe (2014) in the article "Corruption in Nigeria: The Possible Way Out" assessed the effect of corruption on the economy of the state and submitted that, "corruption... reduces economic growth, enhances inequalities and reduces the government's capacity to respond to the people's needs. All these swerve down to create poverty in the society" (34). Corruption creates drawbacks in any given society; it is in itself an unethical behaviour that that hinders the goals of egalitarian ends. Moreover, corruption, such as the political type, occurs at the apex positions of the state and has great political consequences (Awusie \& Okiche 2017: 2). This variant undermines all vestiges of transparent efforts towards sanitizing the public sphere. Aside from the fact that corruption prevails at positions of authority and grass-root levels, all sections of contemporary society are bedeviled by this singular vice.

\section{Oppression}

M. Deutsch in Social Justice Research sees oppression as a form of recurrent injustice involving the legal system in a non-violent manner within the context of social existence. He notes that it is “...the experience of repeated widespread systematic injustice. It needs not to be extreme and involves the legal system (as in slavery, 
apartheid or the lack of a right to vote), nor violence (as in tyrannical societies)" (10).

In lending credence to the oppressed as a known subjugated group in the society, F.J. Donner in Protectors of Privilege x-rays the form of oppression, which favours the privileged strata of society. He opines that "...the oppressed is one on whom authority or power is exercised in a burdensome, cruel or unjust manner" (4). This view is similarly emphasised by Colette Guillaumin in Racism, Sexism, Power and Ideology. However, the distinction lies in the use of coercion as the "act of subjugating one by cruelty, or the state of being kept down by unjust use of force or authority" (36).

A.G. Johnson identifies the categories or groups caught in the web of oppression in society. A group gains an undue advantage over the other through a form of organized abuse of the other group. To him, oppression is, "a concept that describes a relationship between two groups or categories of people in which a dominant group benefits from the systematic abuse, exploitation and injustice directed towards a subordinate group" (48).

However, J.I. Charlton gives a socio-structural understanding on why oppression takes place. He posits that "oppression occurs when individuals are systematically subjected to political, economic, cultural, or social degradation because they belong to a social group, from structures of domination and subordination and, correspondingly, ideologies of superiority and inferiority" (39).

R.L. Barker corroborates Charlton's view on oppression as "the social act of placing severe restrictions on an individual, group or institution.... The oppressed individual or group is devalued, exploited and deprived of privileges by the individual or group, which has more power" (200). Abel Oshevire in Corruption: The 
Big Issue, attributes the problem of Nigeria and African societies to corruption and oppression. He notes that:

The problem of a country like Nigeria and most other African countries is corruption...Given the enormous resources God has blessed us with, it is a shame that we are in a situation where nothing works, hence the poor masses feel oppressed by the actions and flamboyant lifestyles of the upper class (38)

\section{Post-independence Disillusionment and Writer's Commitment:}

Post-independence marked African leadership departure from colonial control to self-rule. Having gained independence from the colonialists, the educated elites, nationalists and intelligentsias that nurtured the desires to transform their societies projected egalitarian ends. However, this expectation was short-lived as, there was a high level of mistrust, unaccountability, dishonesty and total mismanagement of public/government resources. This period, in virtually all African countries and Nigeria in particular, birthed a bourgeoning of criticisms from writers and change crusaders who grew weary of the socio-political and socio-economic despoliations pervading their domains, as the wishes and aspiration of the populace as witnessed in this dispensation, were futile leading to disillusionment. E.N Obiechina, in Language and Theme, discussing Post-colonial/post-independence disillusionment notes that:

...people were made to believe that political independence would usher in the millennium, solve all social problems and create a fuller life for everyone, so much was promised and so little was to be realized or indeed was realized ... in the wake of euphoria that came with independence, better 
prospects were held out to the masses.... They included a commitment to equal opportunities in education, health and employment ... with a few years of independence, the hopes had collapsed and disillusionment had set in. (121)

Between the 1960s and 1990s in Nigeria, successive military and civilian governments emerged onto power with the hope of revamping the nation and its economy, all to no avail. From the 1990 s to the 2000s, the same issues of political ineptness, corruption and oppression are debated with no viable solutions in prospect. In the literary scene, Nigerian poets rose to cast satiric aspersions on these vices because they provoked and threatened the country's developmental trajectory, while its future seemed predictably bleak in the hands of the corrupt political elites. Awuzie \& Okiche (2017) describe this situation with poetry during post-independence in Africa: "African poetry now seems to affirm that the ruling elites have derailed the dreams of Africans true independence and that corruption is now a major factor that has hindered the growth and development of African societies" (1)

The artistic consciousness exhibited by African poets, especially those of Nigeria extraction, have over the years increased impressively, following their investigations into the ideological cum socio-political impetus in their domains from independence to the contemporary period. Onukaogu and Onyerionwu (2009) note that, "...the contemporary situation with all its exigencies has driven the African creative writer to the genre that grants him/her the ambience to interiorize and mediate about his place and role in the scheme of things" (137).

The majority of the poets, whose masterpiece offer updates on the challenges of state politics, have seen the light of this day. 
Very few audacious and brave voices have offered to interrogate the sociopolitical despoliations of their domains as they tugged at the heart of the public sphere from one successive government to the other. Such devoted and artistic poets in their commitment to the course of rejuvenating the nation's key institutions include: Wole Soyinka, Gabriel Okara, Christopher Okigbo, Hyginus Ekwuazi, Niyi Osundare, Tanure Ojaide, Ezenwa-Ohaeto, Hope Eghagha, Idris Amali, Akachi Ezeigbo, Remi Raji, Harry Garuba, Musa Okpanachi, Odia Ofeimun, etc. Poetry for them embodies Rao and Visakhapatmam's (2002) standpoint as:

.... a powerful medium through which they convey to the world audience, not only their despairs and hope, enthusiasm and empathy, thrills of joy and the stab of pain, but also a nation's history as it moved from freedom to slavery, from slavery to revolution to independence and from independence to tasks of reconstruction which further involved situations of failure and disillusion. (Cited in Onyekachi \& Onyerionwu 2019: 51).

The Nigerian poet's responsibility to politics of the public sphere and society is envisioned in the explorative ideology of arts for humanity's sake, as expressed in those creative materials for chastisement and warning. This posture serves to reminder us that the moral gods governing societies, are watchful of man's excesses. Therefore, Jean Paul Sartre rightly argues in Sami (2011) that such, "Writers commit themselves to a cause and condemn the old theory of art's sake. They give society a guilty conscience and are totally in a state of antagonism towards the conservative forces, which 
maintain the balance they want to upset" (38). Similarly, Ifemesia Iferenta affirms that:

In a ... society where oppression, deprivation and dehumanization form the bulwark of society's superstructure, it is balmy and distastefully defeatist for an artist to recoil into an indifferent shell of creative fantasy, celebrating Art-for-Art's sake; that the artist cannot write or sing about mushy love songs or scripts when his immediate surroundings are engulfed in a conflagration. The artist's sublime task is to put out the pillaging flames first: then later, as a form of catharsis, he can write queasy love ditties to his estranged heartthrob. (18)

Interestingly, the addition of Akan Essien and Halima Amali's poems, makes the task of art for humanity sake viable in their meditative quest towards social and political inquiries. Thus, Chinua Achebe's cautions in 1968 of the African scholar's expectation, where he notes that, “...the African creative writer who tries to avoid the big social and political issues of contemporary Africa will end up being completely irrelevant.... (Cited in Cartey and Kilson, 1970: 162).

\section{Nigerian Postcolony and Poet's Intervention}

Ashcroft, Griffiths and Tiffin (2007) posit that the term postcolony "has been largely associated with the Francophone Cameroonian critic Achille Mbembe who has written several influential accounts of how power and oppression actually work in the postcolonised states in Africa" (175). This concept describes nations once under the domination of the colonial power, whose contact with the 
colonizers, generated myriad issues of violence and oppression in polemical writings. Thus, the economic, political and cultural relations with the West may have birthed what is logically termed postcolonial literature, that is "...literature written by writers of countries that have gained political independence from a colonial power (Okoye 2013:1). The concept not only includes literatures that "critique colonialism but also include works that indict the indigenous leaders believing that the problems of many African countries after independence can be traced to the historical experiences of colonialism" (Ogbazi 2007:49).

The Nigerian postcolony is characterized by lachrymal experiences that gave rise to the intervention of poets and writers of successive generations. Anyone familiar with the periodic growth/phases of its poetry will agree that though, critics and writers share diverse sentiments on Nigerian poetry across generational line, it has widely been accepted as a template for measuring and situating poetry based on historical precedence. While the 'first generation' poets preoccupied themselves with pre-colonial themes, the 'second generation' poets redirected their poetic arsenal after independence; it is the third generation of poets mostly in the 1980s that left an impressive mark in their anti-government/military advocacy. Their poems fine-tuned and reinforced the temper of postcolonial challenges in Nigeria.

Indeed, postcolonialism signaled the official ending of imperialist domination by most third world countries, elitist nationals and political powerhouse in Africa grew nationalistic to those mass-driven agenda by countries within regional landscapes. In West Africa, the Nigerian poet wore the egalitarian robe of selfgovernance, highlighting the perennial dislocations and concomitant discomfitures in the heart of political ineptness. 
However, while the creative outcrops of postcolonialism in Nigeria featured poet's experimentation with, and the domestication of issues after independence, the significance of the discourse nurtured the pivotal afflatus for inventive extemporizations. They are fundamental depiction of the tensions, squabbles, wars, tribal/ethnic bigotries, corruption, oppression, marginalization, militarization, capitalism, exploitation, economic fraud, moral decay, underdevelopment and neo-colonialism. Poets like Ezenwa Ohaeto, Odia Ofeimun, Niyi Osundare, Tanure Ojaide, Gbemisola Adeoti, P.O.C. Umeh, Ifowodo Ogaga, Harry Garuba Joe Ushie, etc., project such post-colonial quandaries as corruption, leadership failure, tyranny and militarisation. Of the many outputs churned out, are those whose poems remarkably offer peculiar reflections in Nigeria such as: Voice of the Night Masquerade (1996), If to Say I be Soljar (1998), The Poet Lied (1980), Go Tell the Generals (2008), Village Voices (1984), The Endless Song (1989), Fate of Vultures (1990), Naked Soles (2005) and Moonsongs (1988).

At various stages in the evolution of Nigerian poetry, some writers, armed with a social vision, fired satiric spears at military dictators while others denounced moral decay by advocating for egalitarianism. It is then no surprise that Ohaeto, one of Nigeria's postcolonial writers, voiced such quandaries in If to say I be soljar (1998), unequivocally ridiculing military politics of oppression and greed in the light of 'pidginization' that uniquely accommodated and fostered the sensibility of the masses. Ofeimun invented an activist anti-military discourse in The Poet Lied (1980) which "pitches the poet against the military" (Okunoye 68). Ojaide's collection - The Fate of Vultures (1990) - recreates an antigovernment discourse on corruption, underscored with great temper and fury. Adeoti's Naked Soles (2005) shares similar experience in 
jagged metaphors of pains and lamentations that Garuba's Animist Chants and Memorials (2017) chiefly represent. Osundare's vision mirrors those of the poor masses as a people poet against the bourgeois politicians in Village Voices (1988) and Song of the Market Place (1983). His poetic strategy "ranges from the parabolic to the dramatic" (Okunoye 71). Therefore, the Nigerian poet's interventionist role continues to be apparent in some recent collections that accentuate and recreate postcolonial predilection particularly, on the problems and challenges of politics, nation building towards socio-political transformation. They include: Premonitions and Other Poems (2005), The Eaters of the Living (2006), I Want to Join Them (2006), I Will ask Questions with Stones If They Take My Voice (2008), Back Again: At the Foothill of Greed (2012), Efeega: War of Ants (2014) Sea of My Mind (2013), Animist Chants and Memorials (2017) and The Questioner (2018). These few collection further adds up to the corpus of Nigerian postcolonial poetics in contemporary times.

\section{Methodology}

The method is textual analysis in the interpretation and analysis of the selected poems. The nature of the work and the topic of the research justify the use of the method. The paper has a study population of two carefully chosen poetry collections - Stabbed Alive. Rage Alive and I Want to Join Them. Seven poems are selected from both collections concerning the topics of analysis. In Stabbed Alive. Rage Alive, "The Driverless Molue", "My Political Manifesto", "The Honourables" and "The Song of a Thief" are selected. In I Want to Join Them, "Seats of Oppression", "Guards of Our Treasury" and "I Hate Them" were selected. The procedure for 
data collection for this study is by library material: scholarly journals, textbooks, and printed mass media.

\section{Theoretical Framework}

Ashcroft, Griffiths and Tiffin (1995) describe postcolonial theory as one involving migration, slavery, suppression, resistance, race, gender, place, problems of global culture, and the relationship between cultures and global forces preceding colonization (2). This colonization process ultimately affects the subalterns with its act of marginalization and oppression. Postcolonialism thus creates an avenue for the oppressed to have a voice by reproducing discourses of exploitation and equating the imbalanced binary relation 'Them' and 'Us'. Onyejizu and Obi (2020:336). Broadly, postcolonial theory examines:

... the initial contact with the colonizer and the disruption of indigenous culture, the journey of the European outside through an unfamiliar wilderness with a native guide, ordering and colonial oppression in all its forms, mimicry (the attempt of the colonized to imitate the dress, behavior, speech and lifestyles of the colonizer); exile (the experience of being an outsider in one's own land or a foreign wanderer in Britain); post-independence followed by disillusionment, the struggle for individual and collective culture identity and the related themes of alienation, unhomeliness and hybridity; and the need for continuity with a pre-colonial past and selfdefinition of the political future. In addition, most post-colonial critics analyse the ways in which a literary text, whatever its themes, is colonialist or anti-colonialist, that is, the ways in which the text 
reinforces or resists colonialism oppressive ideology Tyson (1999:374)

Postcolonial theory has produced varying discursive terminologies such as Homi Bhaba's Hybridity, Edward Said's Orientalism and Gayatri Spivak's Subalternity. There are other concepts, which serve to underpin diverse perspectives on postcolonial studies such as neo-colonialism, Third World (First, Second), slavery, binarism, Manichaenism, aborigine, appropriation, colonization, centre/margin (periphery), worlding, Commonwealth, hegemony, Diaspora, identity, mimicry miscegenation, abrogation, colonial ideology, hegemony, etc. Any postcolonial textual analysis may mirror the clarification Robert Young (1995) offers. To him, it seeks:

... to reexamine the history of colonialism from the perspective of the colonized; to determine the economic, political, and cultural impact of colonialism on both the colonized peoples and the colonizing powers; to analyze the process of decolonizatison; and above all, to participate in the goals of political liberation, which includes equal access to material resources, contestation of forms of domination and articulation of political and cultural identities. (11)

This paper adopts spivak's postcolonial approach to unravel the internal dynamics of corruption and oppression by political oppressors against the oppressed or marginalized masses in Nigeria. The Italian Marxist, Antonio Gramsci's Prison Notes (1948), was instrumental to the development of postcolonial subalternity. This theory helps to comprehend the conditions of the oppressed in post- 
colonial societies. Morton (2003) historically views subalternity "as the general attribute of subordination in South Asian society whether this is expressed in terms of class, caste, age, gender and office or in any other way" (48).

In this paper, subalternity is used as an attempt to examine the status quo of the subordinate class/masses in the Nigerian society. There are limitations to the application of subaltern resistance as seen in the manner the public react to their oppressed situation. To this end, Tilwani (2013) submits: "The term, subalternity, is remarkably and aptly employed by spivak, to highlight the predicament of those who are allotted 'sub' or 'secondary' space in human society. Subatern is used as an umbrella term for all those who are marginalized and deprived of the voice to 'speak'" (113).

\section{Results and Discussion}

Stabbed Alive. Rage Alive was published in 2010 by Siene Books, Uyo, Nigeria. The collection consists of thirty-six poems, divided into three sections as 'stabbed Alive,' 'Flirtations' and 'rage Alive.' The first section focuses on bad governance, unraveling the subject of oppressive politics. The second, 'Flirtations,' gives a bird's eye view on the subject of lust and beauty recreated in the poet's imaginary world. The last, 'rage Alive,' anticipates a revolutionary warfare against human force of oppression. The blurb section of the anthology substantiates that:

...poetry is a pointer to what would soon transpire when people oppressed decide to take hold of their destinies ... from their oppressors. In Stabbed Alive. Rage Alive, the rage from a people oppressed would become bloody if their oppressors would not stop the stabbing of the people through deceit in the name of 
doing service when they are only working for their egocentric end. (Blurb n.p.)

In "The Driverless Molue," the poet, deploying molue as afflatus, mirrors the paucity of transparent politics of Nigeria and the endless dilemma of the culture of oppression on the Nigerians. The term molue derives from the Yoruba word 'móòlue,' which means a privately-owned commercial bus with forty-four passengers seat, used for public transport in Lagos state. By deploying this vehicle as an underlying metaphor, the poet describes Nigeria as a failed state - a country lacking in visionary leadership. The socio-political bedevilment of the country by manifold predicaments gives rise to a mounting hydra-headed cyclical impasse, which the molue represents. The poet's use of molue as an extended metaphor for the country, transiting toward an indefinable destination, is artistically given flesh and blood to predict the future of its society. Thus, the vehicle appears driverless, indicating the directionless deportment witnessed in the subsisting goals and aspirations of the nation. The poet views Nigeria as a state of grit, where sufferings intermingle with fraud and looting of the nation's treasury; a situation where transparency and accountability are jettisoned. The outcomes, being socioeconomic despair and cynicism, go a long way to exacerbate Nigeria's driverless state. In the first stanza, there is pessimism that permeates the country's state of affairs and endowments in the poet's description: "The state of green/ a state of grit. /The state of white/its taste of wails. /Wallop in breeze/of grease and freeze/frail, fraught, flu, fraud/our molue,/ colourful /driverless/but still/in motion" (2). This molue, despite being in motion, gives a grim and sordid picture of the country, portrayed of those politicians who swindle and pillage the nation's resources. The consistent use of 'chaotic' metaphors serves to 
highlight the degree of corruption and oppression in the land - a condition in dire need of reform. Indeed, Nigerian leaders have plundered the state of green, which characterizes her rich vegetation or resources, while the peaceful nature of this society has culminated to unrest, wailing and unnerving hullabaloo. Yet this ill-fated society is presided by corrupt-ridden fraudsters, holding onto power for too long. The dictions such as 'grit,' 'wallop,' 'grease,' 'freeze,' 'frail,' 'fraught,' 'colourful' are used literarily to depict the current state of affairs of the country. Indeed, there is total indifference to the challenges confronting the country in the face of widespread impunity in governance. The poem further laments the growing state of hopelessness and despair as witnessed on a daily basis. This, the poet, substantiates by the use of apostrophe and rhetorical questions to dissect such weaknesses and to ask pertinent national questions, thus: "Oh! Driveless molue/who pulls you gears/when you burst /into speed of violence?/Oh! Driverless molue /who fires your fuel/to run races fraught/in moral burden/in elections /of crippled trust? (3). In the succeeding verse, the poet refers to the drivers, that is, Nigerian leaders as "crooks in rooks/thieves in sieves...." (3). These men are bereft of the desirable leadership ideal that is capable of galvanising transformation that can alleviate people-plights. Connotatively, molue represents the country while the passengers are Nigerians. The driver is a leader who drives without direction. The driverless state of the country shows that there is no leader. In the poet's view, the leaders are, “... in charge/forcefully/against the wishes of the passengers/in the molue/hapless to/the forceful/takeover/of the driving controls" (4). This driverless molue houses political deceivers and scammers who are far removed from the reality that confronts the electorates. The wobbly movement of the country's molue betrays the degree of inconsistencies witnessed 
in the leadership sphere. It becomes glaring to anticipate the snowballing of the country into uncontrollable conflicts if nothing is done to redirect it to the path that may ameliorate the sufferings of the passengers and meet their earnest needs:

Our molue

galloping aimlessly

puppet driven

in clutches

of wondering speed

fractures many

with

pains, anguish

as the passengers

gulp failed promises

made on

Chameleon excretes

by those Chameleons

in their desires

to be invincible hands

driving our molue

to shrieks and shreds (4)

The country is certain to collapse if it continues to be led by puppets, masquerading as messiahs, thereby creating untold misery. More so, the poet's use of 'chameleon' and 'invincible hands' describes the cruel nature of politicians who offer themselves as demi-gods to the people's chagrin. This chameleonic attribute creates a strong impression of a mischievous looking reptile whose outer layer changes as its milieu changes. Thus, every politician is a 
chameleon whose words and mien change as he ascends the position of authority.

In 'My Political Manifesto,' the poet relentlessly ridicules political party candidates and affiliates who engage in the rhetoric of treachery and falsehoods to perpetrate acts of corruption and oppression against the electorates, negating their yearnings, aspirations and expectations. In a sardonic tone, the poet captures the persuasive audacity, which some self-acclaimed party bigwigs and election candidates employ to ensure victory during elections and at campaign rallies that may permit for complex forms of ignoble and acrimonious crimes with unabated impunity. All assurances of goodwill for the masses and their plights by these politicians are subsumed in the poet's diction:

I am the candidate with strange grace

I will build broad and narrow roads once I am given your mandate

to deliver a jobless

agenda of torrid era (19)

Interestingly, the 'candidate with strange grace' is an oppressor who guarantees paradise on earth. This hardly comes to fruition. During elections, it is common to notice politicians striving through media adverts to request their followers' support for improved infrastructure, constant electricity supply, food security, quality education and social security. Thus, the poet unravels the devious method used by power-mongers that seems more concerned about self-seeking policies and political parties than for the people in the succeeding stanza:

In my rule

Caesar would have his dues 


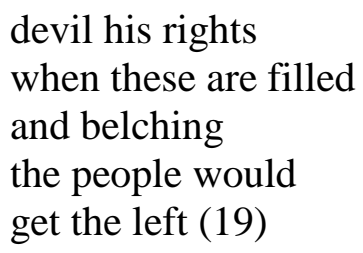

The poet further exposes a leadership ethic that condones miscreants; specifically, Caesar and the devil that are free to unleash terror. By implication, their empowerment is to plunder the state's until they are satisfied, leaving little or nothing for the masses. Administratively, the politicians compel the citizens to pay excess tax with coercion. The use of force is symbolically represented by harsh government policies and hapless tax officers or "demons" who set up their "scorpion's bites" and "snake poison" to discharge their duties. Hardly are the taxes effectively managed when they are collected to ensure that any feasible plan of the administration is achieved. Rather, the funds are laundered into the personal accounts of political elites:
My administration is in a hurry
I would hurry you to pay tax with scorpion's bits
sons for demons to collect them
into god's sockets
for unhindered *tarzace
because I need their hands
to hand my manifesto
on crippled mandate (19)

Food availability and accessibility are undeniable needs of the electorates. In this case, those electorates who yearn for this 
necessity are denied access to food only if they have obtained the party's logo. What is relatively astonishing is that these key areas of human necessity only become used as bait when elections are at hand. All impending projects by party candidates, though rendered in lip service, only end up as written documents. Thus, in the postelection period, when winners recount their victories and losers decry their losses, such projects are either suspended or abandoned. During execution, the inputs are poor with little emphasis on quality and durability, culminating in potholes and a high mortality rate due to regular accidents. Using subtle sarcasm, the poet satirizes party manifestoes that fail to address in practice, the realities of the society:

\author{
The roads I will build Heavens \\ would weep \\ each time they receive \\ unwanted visitors \\ and Hell happy \\ in their fellowship (20)
}

It is an undeniable fact that hunger and food insecurity result in malnutrition and disease. This is an obvious truth, but the government does not deem it fit to remedy this challenge through viable policies that reflect food and health needs. Worse still is the fact that there is a lingering problem of electricity, which has incapacitated businesses and culminated in unusual darkness. The poet, whose positive cause, is felt in the exposition of the misgivings of the political class, does not refrain from baring his mind on these events:
As for food security, you must have my party's tattoo before you are fed. 
I will make light become

darkness and darkness itself

a continuous dysentery

in your dungeons

of persistent hunger (20)

The next issue addressed by the poet in the succeeding stanza is education and its declining quality. The quality of education has declined so much so that this leads to cyclical illiteracy and brain drain. It is the government's responsibility to ensure that this key sector of the country is reformed to meet people's needs and expectations, but the end to the challenge in the education sector is far-removed from remedying. And because most politicians who are elected into offices are not visionary and literate enough to discern this need, their failure further impacts negatively in the educationally vested plans, projects and policies for the public who perceive education as a necessary means to a greater end:

Since I was born wise,

the education of your children

would be like pounded yam

slapping pounded yam.

They would be stuck in

illiteracy upon illiteracy

until world without end (20)

A cursory $\mathrm{x}$-ray of the last stanza reveals the barefaced reality customary in Nigeria. The poet, by recapturing the illusory rhetoric of politics, exposes the intrigue of political officeholders. In this stanza, he further implies that society's underdevelopment arises when non-performing politicians are re-elected into public spheres. Thus, underdevelopment will have a profound negative effect not 
just in the education sector, but also on lives in the country as security, infrastructure, agriculture, health, science and technology, and the overall development in the country will be affected:

I must always be elected

anytime I want and anytime

I need a post to persist

my manifestos even when

I am drooping in morals

and dead in conscience (21)

In "The Song of a Thief," the poet captures the universal belief that every politician is a potential thief. Deploying the first person narrative emphatically, "I" as if communicating the mind of a sly politian, whose voice is misplaced, he untangles the myth of servanthood, which inundates us with vicious falsehood and pretension. This is exacerbated in the poet's mellifluous diction. Thus, by casting serious glances at the illusory items of party manifestoes, which typify moribund documents in the electoral rhetoric, the intent on defrauding becomes glaring:

I would be your servant

and you would be my master

I have a call to serve

and not to be served

I would wait for you

to be "belly full"

before I eat

...I'm under oath

to deliver

dividends of service... 
In "The Honourables," the poet paints a disconcerting picture of the politician's demeanour. The 'honourables' are politicians whose impression of them, coupled with their mannerisms, radiate with loud sirens and undeserved opulence as well as excessive loot, moral abuse and brutal impudence towards the masses. Indeed, like demi-gods, they are highly celebrated than they would ordinarily have been in a rational, transparent and noncomplacent society: "Tat! Tat! Tat! Tat! /Cry the guns./Lunatic sirens dance amok/Screeching tyre run with loots/ Scarlet Peugeots swerve in, /with rot of abuse/ the honourable is in town./ White brocades are dusted brown/ cars on their right/ wheel to a jam lock/ whips tea skins and skulls,/the honourable must be appeased" (26). In addition, elders and clergymen who are worthy models of morality in their respective societies have become credulous objects of ridicule by politicians. They are mere stooges and gullible followers in their affiliations with the politicians whose praises they sing and whose money they are eager to receive as bribes to forestall the truth that betrays their worth and host communities. The more these politicians are verbally eulogized at village centres and pulpits, they more 'polluted envelops' they receive from their masters: "Elders prostrate, clerics grin/for shrouded gifts of polluted envelops/delivered with promises of more/if sermons,/at village squares and pulpits/are brutalized into convenience/for the reelection of the honourable...." (27).

The second collection, 'I Want to Join Them', is Amali's first published collection of poetry, which addresses serious issues from politics, class-consciousness, oppression, corruption, poverty, marginalisation, etc. Published in 2016 by Kraft limited, the collection addresses key issues that tug at the fabric of governance and the downtrodden in Nigeria. Interestingly, it seems that the 
extent, to which the poet makes her revelation known, shows the urgent need for a just socio-political system, devoid of endemic corruption and oppression. With a timely revelation of the persistent lachrymocities of bad governance, and socio-economic disequilibrium, occasioned by massive corruption of the lachrymators, whose excess abuse of power and opulence, oppress the masses, the poet revisits the twin debacles to Nigeria's advancement. The collection is divided into forty poems in five successive sections - "We Shall Pull Them Down", "I want to Join Them", "The Call", "Emotions" and "Where is the Era?" Mohammed L. Mele briefly gives an update on the novelty of language, literary device and thematic preoccupations in the book, that the:

... collection is fresh, bold and honest in its keen assessment of the social reality of our nation. Though the poet uses clear language, it is amazing that she is able to create distinctive, new, strong and complex imagery. Her straightforward observations reveal serious issues not spoken about; she speaks the unspoken and fearlessly challenges the purportedly unchallengeable. Most interesting is that all her observations and judgments tally with the facts of politicians' demeanours in Nigeria. (Blurb n.p.)

In "Seats of Oppression", Amali did not hesitate to decry corruption and oppression in their unsavoury shades. She is of the view that corrupt politicians who oppress the public should be brought to justice. She makes a virulent decree to uproot these 'clogs' in the wheel of Nigeria's progress, which have spread to all sectors of the country with particular focus on its politics, which, like a wildfire, 
has engulfed everyone, including the poet. Indeed, the politicians, whose ulterior motive, is to feed fat from the nation's treasury, are to blame for their lack of progressive and transforming vision, which the country would have had if they had the country at heart. The positions occupied by the politicians are oppressive to the masses because they run counter to their standard of living. Thus, while the politicians appear nourished and healthy, the masses barely have enough to feed:

They seat tight

On ballooned buttocks

Jeering at us

From their elevated seats

Oppressive to man (31)

All the attributes of the politicians outlined by the poet, are not only vile but also morbid, and points to the fact that nothing genuine can come out of political officeholders. Thus, their state of opulence, devious antics and sinister intents for the downtrodden are facts that accentuate the poet's observation:

We watch them

On their seats on the hallowed platform

From where these oppressors of man

Rock on mountains of money

palpating corruption for a living

And harbouring evil.

We decry their seats of oppression

Cordoned by theft and illicit deals

Depriving the rich a feeling for the poor

As they roll in affluence

For showers of fraudulent deals (31) 
The seats of oppression are the positions of authority and power, which the politicians occupy for their enrichment and the perpetuation of illegalities and crimes against humanity such as 'illicit deals' and undetected 'theft' or stealing. These machinations take place against the will of the public. Consequently, the more successful the politicians are in such activities, the more sophisticated they become in their next journey. In the fourth stanza, the poet makes a revolutionary declaration to pull the 'carnage' down to revive the country's treasury:

We shall deflate these men

From their seats of oppression

Punctuating their ballooned bodies

Filled with our wealth

And revamp our treasury

We shall hijack their stands

Pulling their seats off

From underneath.... (31)

In "Guards of Our Treasury," the poet lambasts those leaders who are fond of making empty promises, assuring their subjects of economic growth and recovery. There is no gainsaying the fact that these guards of our treasury; that is, the political representatives the president, ministers, senators, legislators, governors, local government chairmen and counsellors, whose responsibility is to manage the financial resources of the public with transparency and efficiency, are agents of retrogression in Nigeria; these public figures disconcertingly mismanage and misappropriate the public treasury. They make self-assured remarks that yield no hope for the masses: 
They come in scores

Honey-tongued

with promises of pious vows

To guard our treasuries

And yield our economic desire

They are voted in thousand of scores

To affirms to their claims and promises

Our eyes rolling bright

In full expectations

Of our guards guarding our hopes (34)

In the third stanza, the poet speaks plainly; she bemoans the rate at which Nigerian representatives at the pinnacle of power, orchestrate financial fraud in the payment of teachers' salaries, pensioners' funds, vigilante's allowances, constituency funds, widow's benefits and those in the society. Besides, their failure to carry out constitutional responsibilities further impedes development at federal, state and communal levels. Descriptive words such as 'thieves', 'fat bellies', ' stolen funds' and 'vultures', help to paint a vivid picture of the kind of leaders the poet detests:

...Woe unto these thieves

With fat bellies creamed in

Unpaid salaries of teachers

Stolen funds of pensioners

Earned allowances of vigilantes

Constituency funds

And benefits of widows

Marginalised into their pocket

I say to you the vultures

Woe unto you 
We await the day of reckoning

When eyes shall bulge and protrude

When eyelids shall shy away

from eyelids (34)

In "I Hate Them", the poet goes from representing the politicians as scoundrels to painting them as leeches. Her temper is vitriolic against those underperforming politicians who view politics as their last call for survival. The poet decries this looting tendencies; this is because it is unethical and leaves a bad precedent for young aspiring politicians:

Our thieving leaders

These thieves at the top

Daily climbing our tower of hope

And pouncing

Onto our reserves of life

Devouring the produce

Like the red monkey in maize farm

I hate them.... (38)

The thieves, 'climbing our towers of hope' and 'pouncing onto the reserves of life', are the unruly politicians who have found a dishonourable means of livelihood. The poet compares them to the 'red monkey in a maize farm'. This comparison leaves much to be desired; this implies that the politicians are ravenous animals whose intent is not only to consume a crop meant for other animals but also to oppress them unflinchingly. The poet also detests the fact that other aspects of the society such as masses impoverished lifestyle, unsafe hospitals housing wild animals, school buildings in a 
dilapidated state, unpaid teachers' salaries and the poor standard of its universities, are contemporary challenges yet to be remedied:

I detest where many live

Unsure of tomorrow

Hospitals remain complexes for rats

School buildings crumble

Teachers wallow in hunger

Universities denigrate to playgrounds

Yet

These stakeholders of corruption in lead in silver in gold

And their skins glitter.... (39)

\section{Conclusion}

The postcolonial experience in Nigerian poetry has revealed that the shared dreams and aspirations of Nigerians were never fulfilled even after independence. Thus, the analysis of some selected poems in the chosen collections shows that the Nigerian poets are at home with the myriads of events that tug at the socio-political sphere of their postcolonial society, which seeks to undermine all efforts directed towards a functional and progressive development. The Nigerian poets, through the ideological stripe of art for humanity's sake, satirized the corruption of the political elites and exposed the persistent antics of oppression of the masses in their poems. These topical issues - corruption and oppression - manifest in some forms of failed egalitarian promises, eating propensity, maladministration, lack of accountability, looting of public funds, excessive opulence and the political rhetoric of deceit before and during election campaigns. This paper, therefore, makes a recommendation for further research in the aspect of Marxist aesthetics. 


\section{Raphael Chukwuemeka Onyejizu} Nnamdi Azikiwe University, Awka, raphaelnjz@gmail.com 


\section{References}

Ashcroft, B, Griffiths, G. and Tiffin, H. Eds., (2007) Post-Colonial Studies. The Key Concepts. Routledge.

............ Eds., (1995) The Post-Colonial Studies Reader, 2nd Edition, Routledge.

Agbese, D. (1992) "Corruption, the Palm Oil that stains the fingers of the Giver and the Receiver" Newswatch. March 9 vol.15, No. 109-115. Pp. 9-15.

Amali, H. (2016) I want to Join Them. Ibadan: Kraft Books Limited. Amundsen, I. (1999) Political Corruption: An Introduction to the Issues. Chr. Michelsen Institute of Development Studies and Human Rights. WP: 7.

Awusie, S \& Okiche, I (2017) "Corruption and Politics in Chukwuma Ibezute's Cries of the Downtrodden" Research Journal of Language, Literature and Humanities. 4(3), 1-4, March.

Baker, R. L. (2003) The Social Work Dictionary. $6^{\text {th }}$ ed. Washington D. C.: NASW Press.

Cartey, W \& Kilson, M. (1970) The African Reader in Colonial Africa. London: Vintage Books.

Charlton, J. I. (1998) Nothing About Us: Oppression and Empowerment.

Davis, K. E. (2002) Expanding the Theoretical Understanding of Oppression. Alexandra Va: Council on Social Work Education. Deutsch, M. (2006) "A Framework for Thinking About Oppression and its Change." Social Justice Research, 19(1), 7-41. Dooner, F. J. (1990) Protectors of Privilege: Red Squads and Police Repression in Urban America. Berkeley: University of California Press. 
Essien, A. (2010) Stabbed Alive. Rage Alive. Siene Book: Uyo.

Guillaumin, C. (1995) Racism, Sexism, Power and Ideology. London: Routledge.

Iferenta, I. (1989) “Art as Custodian of Conscience." The Guardian Sunday Supplement. May 7, 18-9.

Johnson, A. G. (2000) Privilege, Power and Difference. Boston: McGraw- Hill.

Khan, M. H. (1996) A Typology of Corruption in Transactions in Developing Countries. Ids Bulletin, 27(2), 12-21

Obiechina, E. N. (1978) "Language and Themes." Nsukka Studies in African Literature. Nigeria: Afro Afro Press.

Ogbazi, I. (2012) History and the Voiceless: Yvonne Vera and the Postcolonial Zimbabwe. U.S.A. Lambert Academic Publishing.

Okolo, P. O. \& Akpokighe, O. R. (2014) "Corruption in Nigeria: The Possible Way Out" Global Journal of Humanity-Social Science: F Political Science. 14 (7)

Okoye, Chike. (2013) Introduction to Commonwealth and Postcolonial Literature. Besing Books.

Okunoye, Oyeniyi. (2011) "Writing Resistance: Dissidence and Visions of Healing in Nigerian Poetry of the military era". TYSKRIF VIR LETTERKUNDE. 48(1)

Onukaogu and Onyerionwu, (2009) $21^{\text {st }}$ Century Nigerian Literature; an introductory Text. Ibadan: Kraft Books Limited.

Onyejizu, R. C. \& Obi F. U. (2020) Ideological Commitment in Modern African Poetry: Redefining Cultural Aesthetics in Niyi Osundare's The Eye of the Earth and Village Voices, 20(2). 
Onyekachi, A. (2019) "National Transformation and African

Literature: A Study of Okpanachi's They are the Eaters of the Living." Journal of English Association of Nigeria, 21(2).

Oshevire, A. (2012) Corruption: The Big Issue. Benin: Ethiope.

Salisu, M. (2000) "Corruption in Nigeria". Lancaster University Management School Working paper series. 2000/006. Retrieved from http://www.lums.co.uk/publicat ions

Sami, G. (2011) "The Power of Fiction: How Literature Educated and Reformed American Society." Journal of Teaching Language Skills. (JTLS) 3(2), Summer 2011, Ser. 63/4 (Previously Journal of Social Sciences and Humanities).

Turner, J. H., Singleton Jr, R., \& Musik, D. (1984) Oppression: A Socio-History of Black-White Relations in America. Chicago, II: Nelson-Hall.

Tyson, L. (1999) Critical theory today. New York: Garland.

Young, R. (1995) Colonial Desire: Hybridity in Theory, Culture and Race. London, Routledge. 